\title{
Evaluating the national PPE guidance for NHS healthcare workers during the COVID-19 pandemic
}

\author{
Authors: John P Thomas, ${ }^{\mathrm{A}}$ Anand Srinivasan, ${ }^{\mathrm{B}}$ Chandu S Wickramarachchi, ${ }^{\mathrm{C}}$ Parveen K Dhesi, ${ }^{\mathrm{D}}$ \\ Yat MA Hung ${ }^{\mathrm{D}}$ and Ajay V Kamath ${ }^{\mathrm{E}}$
}

Tragically, many of the infections and deaths recorded in the global coronavirus disease 2019 (COVID-19) pandemic have occurred in healthcare workers. Some have attributed this to inadequate provision of personal protective equipment (PPE). In the UK, several organisations have voiced their concerns that the national PPE guidance issued by Public Health England is inadequate. Despite recent revisions to these guidelines, concerns remain that they offer insufficient protection to frontline NHS healthcare workers. In this report, we evaluate whether these concerns are merited, through critical appraisal of the available evidence, review of international PPE guidance, and consideration of the ethical implications.

KEYWORDS: COVID-19, personal protective equipment, pandemic, NHS, SARS-COV-2

DOI: $10.7861 /$ clinmed.2020-0143

\section{Introduction}

The coronavirus disease 2019 (COVID-19) pandemic has indiscriminately thrown healthcare systems across the globe into turmoil. The public health strategy adopted by the UK Government will ultimately determine the outcome of the battle against COVID-19 on our own shores. Protected by modern healthcare, it is reasonable to assume we will eventually win this battle - but at what cost?

Tragically, many of the infections and deaths recorded in this global outbreak have occurred in healthcare workers (HCWs). HCWs account for $9 \%$ and $13 \%$ of the total confirmed COVID-19 cases in Italy and Spain respectively. ${ }^{1-3}$ On 17 April 2020, the

Authors: ${ }^{A}$ National Institute for Health Research academic clinical fellow, Norfolk and Norwich University Hospital, Norwich, UK; Bfoundation trainee, Oxford University Hospitals NHS Foundation Trust, Oxford, UK; ' senior house officer, Havering and Redbridge University Hospitals NHS Trust, Romford, UK; Dsenior house officer, Norfolk and Norwich University Hospital, Norwich, UK; ${ }^{\mathrm{E}}$ Consultant respiratory physician, Norfolk and Norwich University Hospital, Norwich, UK
Italian National Institute of Health announced that nearly 17,000 $\mathrm{HCW}$ in Italy had contracted the illness. ${ }^{4}$ Shortly afterwards, the Italian Federation of Medical Associations (FNOMCeO) reported that 139 Italian doctors had so far died of the disease. ${ }^{5}$ In the UK, as of 28 April 2020, the Government have verified 49 deaths among NHS HCWs due to COVID-19 during the pandemic, although other organisations report that the actual figure may have surpassed 100 deaths. $^{6}$

Frontline NHS HCWs and organisations such as the British Medical Association (BMA) and Doctors' Association UK (DAUK) have consistently voiced their fears that the national personal protective equipment (PPE) guidelines issued by Public Health England $(\mathrm{PHE})^{7}$ are inadequate to offer sufficient protection - both in terms of quantity and quality. Despite several revisions to the PPE guidance by PHE since the early stages of the pandemic, there are still concerns that the recommendations remain sub-optimal. ${ }^{8-10}$ In this report, we evaluate whether these concerns are justified through comparison of global PPE guidance, evaluation of the scientific basis of PPE, and consideration of the ethical implications.

\section{Global PPE guidance vs Public Health England PPE guidance}

Since the first reports of the outbreak, multiple governing bodies have published recommendations for institutions under their jurisdiction, both to protect the health of the caring workforce and mitigate COVID-19 propagation through the healthcare environment. There has been a remarkable degree of congruence between these various recommendations in secondary care settings (shown in Table 1). It appears that even following several revisions, the PHE guidance (as of 24 April 2020) falls short of its counterparts in many clinical scenarios (Table 1). Although the guidance now recommends respirator masks, disposable surgical gowns and eye/ face protection when performing selected 'aerosol-generating procedures (AGPs)' or working in specific 'higher risk acute care areas' with possible/confirmed cases, in other clinical settings such protective measures are deemed unnecessary. For instance, the PHE guidelines still translate clinically to frontline HCWs caring for suspected and confirmed COVID-19 patients in most inpatient wards (which are considered not to be 'higher risk acute care areas') with the protection of a surgical facemask, disposable gloves, plastic apron, and face shield/goggles subject to risk-assessment and proximity to the patient. Furthermore, the guidance suggests that surgical facemasks and plastic aprons are sufficient for those 
Table 1. Global comparison of personal protective equipment (PPE) for healthcare workers in secondary care settings when providing care for patients with suspected/confirmed COVID-19

\begin{tabular}{|c|c|c|c|c|c|c|}
\hline & $\begin{array}{l}\text { World Health } \\
\text { Organization }^{24}\end{array}$ & China $^{69}$ & $\begin{array}{l}\text { ECDC (Italy, } \\
\text { Spain, France, } \\
\text { Germany) })^{70}\end{array}$ & CDC (USA) $)^{71}$ & Australia $^{72}$ & PHE $\left(\right.$ UK) ${ }^{7}$ \\
\hline $\begin{array}{l}\text { Respiratory } \\
\text { protection }\end{array}$ & $\begin{array}{l}\text { Medical } \\
\text { facemask }^{*}\end{array}$ & $\begin{array}{l}\text { N95/FFP2 } \\
\text { respirator mask }\end{array}$ & $\begin{array}{l}\text { FFP2/FFP3 } \\
\text { respirator mask }\end{array}$ & $\begin{array}{l}\text { N95 respirator } \\
\text { mask }\end{array}$ & $\begin{array}{l}\mathrm{N} 95 \\
\text { respirator mask }\end{array}$ & $\begin{array}{l}\text { Fluid-repellent } \\
\text { surgical mask* }\end{array}$ \\
\hline Body protection & $\begin{array}{l}\text { Long-sleeved } \\
\text { gown }\end{array}$ & $\begin{array}{l}\text { Long-sleeved } \\
\text { medical } \\
\text { protective } \\
\text { uniform } \\
\text { Shoe cover } \\
\text { Hat }\end{array}$ & $\begin{array}{l}\text { Long-sleeved } \\
\text { water-resistant } \\
\text { gown }\end{array}$ & Gown & $\begin{array}{l}\text { Long-sleeved } \\
\text { gown }\end{array}$ & $\begin{array}{l}\text { Plastic apron }{ }^{\ddagger} \\
\text { Bare below the } \\
\text { elbows }\end{array}$ \\
\hline $\begin{array}{l}\text { Eye protection } \\
\text { (face shield or } \\
\text { goggles) }\end{array}$ & Yes & Yes & Yes & Yes & Yes & $\begin{array}{l}\text { Dependent on } \\
\text { clinical setting, } \\
\text { proximity to } \\
\text { patient and/or } \\
\text { risk assessment }^{\S}\end{array}$ \\
\hline $\begin{array}{l}\text { Hand protection } \\
\text { (gloves) }\end{array}$ & Yes & Yes & Yes & Yes & Yes & Yes \\
\hline \multicolumn{7}{|c|}{$\begin{array}{l}\text { *Respirator masks are only recommended if performing selected aerosol-generating procedures (AGPs) or also in the UK if working in higher risk acute care areas } \\
\text { (defined by PHE as: 'ICU/HDUs; ED resuscitation areas; wards with non-invasive ventilation; operating theatres; endoscopy units for upper respiratory, ENT or upper }\end{array}$} \\
\hline \multicolumn{7}{|c|}{$\begin{array}{l}\text { 'In the absence of FFP2/3 respirator masks, healthcare workers should use masks with the highest available filter level. Respirator masks can be used for up to } \\
4 \text { hours for multiple patients without removing them, unless the respirator is damaged, soiled or contaminated, for example a symptomatic suspected case } \\
\text { coughing on them. }\end{array}$} \\
\hline \multicolumn{7}{|c|}{$\begin{array}{l}\text { FDisposable fluid-resistant gowns or coveralls to be only worn if performing selected AGPs or working in higher-risk acute care areas or in operating theatre/labour } \\
\text { ward area with possible or confirmed case. }\end{array}$} \\
\hline \multicolumn{7}{|c|}{$\begin{array}{l}\text { Eye/face protection should be worn if working in a higher risk acute care area/labour ward/operating theatre with possible or confirmed case or when performing } \\
\text { selected AGPs or if in close proximity (ie }<2 \text { metres) to a possible or confirmed case in an acute assessment/inpatient/maternity/radiology area. In other instances, } \\
\text { eye/face protection should be worn if following an individual risk assessment there is thought to be an anticipated/likely risk of contamination to the eyes from } \\
\text { splashes, droplets of blood or body fluids. }\end{array}$} \\
\hline \multicolumn{7}{|c|}{$\begin{array}{l}C D C=\text { Centers for Disease Control and Prevention; ECDC = European Centre for Disease Prevention and Control; FFP = filtering face piece; PHE = Public Health } \\
\text { England }\end{array}$} \\
\hline
\end{tabular}

undertaking procedures which do not fall within the criteria of 'potentially infectious AGPs for COVID-19' - notable examples within this excluded category include collection of nasal/nasopharyngeal swabs, cardiopulmonary resuscitation and administration of highflow humidified oxygen.11 As demonstrated, the PHE PPE guidance appears complex and convoluted in comparison to its counterparts which have adopted far more uniform, simplified yet enhanced PPE measures across secondary care settings.

\section{Scientific basis of PPE}

\section{Transmission}

Current evidence indicates that SARS-CoV-2, as with SARS-CoV-1, may be spread by four major routes: direct or fomite contact; respiratory droplets generated during coughing or sneezing; faeco-oral; and airborne via aerosols. ${ }^{12,13}$ Airborne and faeco-oral transmission have the potential to result in super-spreading events particularly in nosocomial settings. . $2,14-17^{-17}$

\section{Aerosols}

While respiratory droplets ( $>5 \mu \mathrm{m}$ ) tend to fall to the ground rapidly within one metre from the source, aerosols $(<5 \mu \mathrm{m})$, by virtue of their size, remain suspended in the air for prolonged periods. ${ }^{15,18,19}$ Coughing and sneezing, two common clinical symptoms of COVID-19, can produce both droplets and aerosols, with particles varying in size from $<1$ to $>2000 \mu \mathrm{m}$, but mostly in the $<20 \mu \mathrm{m}$ range. ${ }^{19-21}$ Speech was recently shown to generate respiratory droplets ranging from $20-500 \mu \mathrm{m}$ in size using a laser light-scattering approach. ${ }^{19} \mathrm{~A}$ recent model of respiratory emissions suggests that droplets and aerosols carrying pathogens may actually spread up to eight metres as a turbulent gas cloud. ${ }^{22}$

Based on a 2013 systematic review, the World Health

Organization (WHO) identifies certain clinical tasks, such as tracheal intubation, suctioning and cardiopulmonary resuscitation, as AGPs. ${ }^{23,24}$ But recent studies report activities including oxygen mask adjustment, physical examination, and intravenous access are similarly aerosol-generating. ${ }^{25}$ Influenza viral shedding has also been observed even during normal breathing in the community setting. ${ }^{26} \mathrm{~A}$ more recent study showed that viral RNA could be found in respiratory droplets and aerosols generated during exhaled breaths from influenza, coronavirus and rhinovirusinfected patients. ${ }^{27}$ Another study found that there was influenza RNA concentration surpassing the infectious dose in all sampled clinical areas providing routine care in a tertiary hospital. ${ }^{28} \mathrm{HCWs}$ 
were exposed to mainly small influenza virus particles (diameter $<4.7 \mu \mathrm{m}$ ) even at distances of $1.829 \mathrm{~m}$ from patients. ${ }^{28}$

SARS-CoV-2 has been shown to remain viable as bio-aerosols for at least 3 hours, and on other surfaces (such as cardboard, plastic and metals) for longer. ${ }^{29}$ Evidence from surface and air sampling from early studies demonstrate widespread environmental contamination in patient care areas by viral RNA, indicating significant aerosol-mediated viral shedding. 12,30,31

Thus with current evidence yet to conclusively elucidate the nature and degree of airborne spread of SARS-CoV-2,32 PPE guidance that risk-stratifies based on the aerosol-generating potential of a clinical activity at specific clinical locations or proximity to a patient may be greatly underestimating the risk. For instance, even in 'low' or 'intermediate' risk clinical settings, such as general medical wards, HCWs may receive significant viral exposure as they encounter multiple COVID-19 patients shedding unpredictable viral loads generated through breathing, speaking or coughing.

\section{Respiratory protection}

The major mask manufacturer $3 \mathrm{M}$ states that surgical facemasks are inadequate to protect the wearer from inhaling particles smaller than $100 \mu \mathrm{m}$, which includes aerosols and most droplet particles generated through sneezing or coughing. ${ }^{33}$ Instead, 3M recommends at least an $\mathrm{N} 95$ respirator mask to protect against inhaling particles of this size. ${ }^{33} \mathrm{~N} 95$ respirator masks have at least a $95 \%$ efficiency of filtering particles $0.3 \mu \mathrm{m}$ in size. ${ }^{33} \mathrm{~N} 95$ is an American standard and is roughly equivalent to the European mask standard of filtering face piece 2 (FFP2) as detailed in Table 2.

Concordantly, in surrogate viral exposure studies with comparison to surgical masks, respirator masks were associated with as much as 15 -fold less filter penetration and aerosol transmission under laboratory experimental conditions. ${ }^{21,34-36}$ Concerningly, live viruses could be detected in the air behind all surgical masks tested. ${ }^{21}$

The few clinical trials comparing respirator masks and surgical facemasks, in the setting of respiratory viral infections, have generally suffered from low power and confounding factors. ${ }^{37} \mathrm{~A}$ meta-analysis of randomised controlled trials (RCTs) concluded that there were no statistically significant differences in preventing laboratory-confirmed influenza infections ( $n=8,444$ participants from five RCTs) and respiratory viral infections ( $n=3,264$ participants from four RCTs) when comparing N95 respirator masks with surgical facemasks. ${ }^{37}$ However, a subgroup analysis of 2,818 participants in three of the four included trials indicated a statistically significant $39 \%$ risk-reduction in respiratory viral infections when using N95 respirator masks in comparison to surgical facemasks. ${ }^{37}$ In the case of SARS-CoV-1, a meta-analysis of seven case-control studies revealed that surgical facemasks

Table 2. Respirator mask standards ${ }^{73}$

\begin{tabular}{ll} 
Respirator standard & Filter efficiency \\
FFP1 & At least $80 \%$ \\
FFP2 & At least $94 \%$ \\
N95 & At least $95 \%$ \\
N99 \& FFP3 & At least $99 \%$ \\
N100 & At least $99.97 \%$ \\
\hline FFP = filtering face piece; N = 'not resistant to oil'
\end{tabular}

significantly reduced the risk of infection in comparison to no mask (odds ratio [OR] 0.32), while N95 respirator masks were even more effective based on three studies (OR 0.17). ${ }^{38}$

Thus, based on manufacturer advice, experimental data and clinical studies, there is insufficient evidence to conclude that surgical facemasks offer adequate protection against SARSCoV-2. Furthermore, focusing on the efficacy of respirator masks in reducing symptomatic infections should not preclude their potential for reducing the risk of HCWs from becoming asymptomatic carriers/transmitters of COVID-19.39,40 Given the higher virulence associated with SARS-CoV-2 in comparison to influenza and other respiratory viruses, ${ }^{41}$ and the current lack of evidence to rule out its airborne transmission, it would be prudent to err on the side of caution while awaiting more definitive studies.

\section{Body, hand and eye protection}

A systematic review of PPE measures for SARS-CoV-138 reported favourable evidence for eye protection (OR 0.10), gloves (OR 0.32), gowns (OR 0.33) and handwashing (OR 0.54). A combination of these methods with respiratory protection was even more effective (OR 0.09). ${ }^{38}$ These approaches have also been proven to be efficacious in the setting of respiratory syncytial virus and influenza. ${ }^{38,42} \mathrm{~A}$ re-analysis of a simulated exposure study using fluorescent stain found that gowns are superior to aprons in reducing contamination caused by simulated splashes. ${ }^{43,44}$ Similar comparisons have also favoured superiority of sealed suits over traditional gown and gloves (OR 0.68).44,45 In the UK, where HCWs follow the 'bare below the elbow' policy, unlike their international counterparts whose uniforms cover the forearms, gowns are likely to provide more skin coverage than apron alone and minimise contamination by respiratory secretions and fomites.

In one study, $62 \%$ of COVID-19 cases had a history of hand-eye contact and $4.68 \%$ presented with conjunctival congestion. ${ }^{46}$ While eye protection has primarily been shown to be effective in the context of respiratory syncytial virus, it has typically been studied when used alongside other PPE. ${ }^{47}$ Of note, published studies do not differentiate between different activities for the risk of transmission via conjunctiva. Face-shields can potentially simultaneously offer eye and respiratory protection, ${ }^{48}$ but provide insufficient protection against aerosols and droplet contamination if used on their own. ${ }^{48,49}$

\section{Cost-effectiveness}

Cost-effectiveness modelling has revealed that utilising enhanced PPE (respirators, gowns and goggles) for all patients would be costeffective in the setting of a pandemic ${ }^{50}$ or a highly virulent disease such as severe acute respiratory syndrome (SARS) ${ }^{51}$ when taking into account the costs associated with medical staff absenteeism and illness due to inadequate PPE. But as real-world studies on this subject are limited, ${ }^{52}$ data from this ongoing crisis should be evaluated to inform future policies on preparation and stockpiling.

\section{Ethical considerations}

To secure ourselves against defeat lies in our own hands, but the opportunity of defeating the enemy is provided by the enemy himself. ${ }^{53}$

In our battle against COVID-19, many factors may lie beyond our control and we recognise that risk cannot be completely mitigated. However, as Sun Tzu posits, our security through defence remains 
our choice, while the breakthrough in overcoming this pandemic might be provided by gaining further insights into the SARS-CoV-2 virus itself. As previously mentioned, prudence in the face of scientific uncertainty would dictate that we favour caution over convenience, which is encapsulated by the 'precautionary principle'. ${ }^{54}$ Furthermore, Beauchamp and Childress' ethical framework encourages us to counterbalance beneficence with non-maleficence. ${ }^{55}$ When acting for the former, ie providing acute healthcare during this pandemic, we must actively safeguard the latter - avoiding both harm to the public when our frontlines become viral vectors, and tragic loss when those staff succumb to illness.

Additionally, if there is insufficient quantity or quality of PPE to protect the workforce, for whatever reason, then our leaders have a moral duty to be open and honest. It is imperative that all frontline HCWs are duly informed of their own personal risks when caring for COVID-19 patients. It is a reasonable expectation to hold our modern governments to the corresponding standards of our modern health professionals: specifically, transparency in decision-making and the duty of candour. ${ }^{56,57}$

\section{Recommendations}

Based on our appraisal of PPE guidance of healthcare organisations across the globe and the available scientific evidence, we believe that there are still shortcomings to the current PHE PPE guidelines. In particular, there is insufficient evidence to suggest that PPE protection standards can be safely lowered when frontline HCWs are not working in specific 'higher risk acute care areas' or not performing certain AGPs as advised by PHE. Given the scientific uncertainty of novel SARS-CoV-2 transmission and pathogenesis, a more precautionary approach is ethically justified. Accordingly, we recommend that PHE urgently amends its PPE guidance to make it simplified, uniform, and enhanced across all secondary care settings/ scenarios - as seen in other healthcare systems across the globe.

We suggest that all NHS HCWs treating any suspected or confirmed case of COVID-19 in any clinical setting or scenario should wear the following PPE:

> Respiratory protection: N95 or FFP2/3 respirator masks

$>$ Eye protection: Goggles or face shield

> Body protection: Long-sleeved water-resistant gown

$>$ Hand protection: Gloves

\section{Practical considerations}

Given the global demand for PPE in this pandemic, we appreciate that it may not be easily feasible to source appropriate levels of stock and fully adhere to the above recommendations. ${ }^{58}$ Nevertheless, guidelines should ideally reflect best practice based on the available scientific evidence rather than be driven by political or organisational factors, particularly when these measures relate to the health and safety of frontline $\mathrm{HCWs}^{52}$ This is especially important in the emergency situation of a pandemic, where reliable national guidance is essential for an efficient and coordinated nationwide response. While local NHS trusts are not mandated to follow all national guidelines (particularly if deemed to be inadequate), trusts must be prepared to justify their actions, and to take into account the medico-legal consequences and ethical considerations of deviating from them.

To ease the demand for PPE and to ensure that it is utilised properly, we recommend that all staff are adequately trained in wearing PPE (for example, through fit-testing of respirator masks and training of proper PPE donning/doffing technique). If sourcing stock proves to be truly challenging, the Government should actively encourage innovative approaches to producing and/or procuring PPE by liaising with research institutions and industry as a matter of urgency. We have already seen the potential of such resourcefulness with examples such as the production of medicalgrade ventilators by Dyson and the assembly of visors by Royal Mint. ${ }^{59,60}$ At the same time it is important to be cautious of homemade PPE which fails to meet medical-grade specifications. For instance, one trial found that cloth masks were significantly inferior to medical-grade masks in protecting HCWs from influenza-like illnesses. ${ }^{61}$ If adequate PPE is still unavailable, then we should consider measures to safely limit the contact of our frontline staff with confirmed COVID-19 patients. Such an approach for ward settings has been proposed by the British Thoracic Society and Royal College of Physicians, termed 'SPACES' (Sharing Patient Assessments Cuts Exposure for Staff). ${ }^{62}$ Additionally, in exceptional circumstances of stock shortages, extended use and reuse of PPE may be necessary, as outlined in recently published PHE PPE guidance which is based on CDC and WHO guidelines. ${ }^{63}$ However, there is limited data on the efficacy of such measures, and existing evidence suggests they have the potential to increase the risk of self-inoculation through contact transmission or re-aerosolisation of contaminated PPE. ${ }^{29,64-68}$ Therefore, any guidance on extended use or limited re-use of PPE must be complemented by appropriate strategies for training staff to minimise self-contamination.

\section{Conclusion}

Through our appraisal of the available evidence and comparison of international PPE guidance, we conclude that the concerns regarding the current PHE COVID-19 PPE advice remain warranted. We recommend further urgent revision of these guidelines to ensure sufficient protection to the NHS workforce during this pandemic.

\section{Acknowledgements}

We would like to thank Dr Russell Phillips, Dr Tim Raine, Dr Rahul Chattopadhyay and Dr Sanjay Budhdeo for their comments, ideas and suggestions for this paper.

\section{References}

1 Chustecka Z. More than 60 doctors in Italy have died in COVID-19 pandemic. Medscape, 30 March 2020. Available from www.medscape.com/viewarticle/927753 [Accessed 31 March 2020].

2 Giuffrida A, Tondo L. 'As if a storm hit': more than 40 Italian health workers have died since crisis began. The Guardian, 26 March 2020. Available from www.theguardian.com/world/2020/mar/26/ as-if-a-storm-hit-33-italian-health-workers-have-died-since-crisisbegan [Accessed 31 March 2020].

3 International Council of Nurses. ICN tells BBC World News viewers: Rising rate in COVID-19 infection amongst health workers requires urgent action. ICN, 2020. Available from www.icn.ch/news/icn-tellsbbc-world-news-viewers-rising-rate-covid-19-infection-amongsthealth-workers [Accessed 31 March 2020].

4 Nearly 17,000 Italian health workers infected with virus: study. The Straits Times 18 April 2020. Available from www.straitstimes.com/ world/europe/nearly-17000-italian-health-workers-infected-withvirus-study [Accessed 21 April 2020].

5 Federazione Nazionale degli Ordini dei Medici Chirurghi e degli Odontoiatri. Elenco dei Medici caduti nel corso dell'epidemia di Covid-19 [List of doctors who died during the COVID-19 epidemic]. 
FNOMCeO, 2020. Available from https://portale.fnomceo.it/ elenco-dei-medici-caduti-nel-corso-dellepidemia-di-covid-19/ [Accessed 21 April 2020].

6 Marsh S. Doctors, nurses, porters, volunteers: the UK health workers who have died from Covid-19. The Guardian, 28 April 2020. Available from www.theguardian.com/world/2020/apr/16/doctorsnurses-porters-volunteers-the-uk-health-workers-who-have-diedfrom-covid-19 [Accessed 28 April 2020].

7 Public Health England. COVID-19 personal protective equipment (PPE). PHE, 2020. Available from www.gov.uk/government/ publications/wuhan-novel-coronavirus-infection-prevention-andcontrol/covid-19-personal-protective-equipment-ppe [Accessed 24 April 2020].

8 Russell P. Updated PPE guidance issued for UK health and care staff. Medscape, 2 April 2020. Available from www.medscape.com/ viewarticle/928020 [Accessed 5 April 2020].

9 Royal College of Surgeons. RCS statement on latest Public Health England PPE guidance. RCS, 2020. Available from www.rcseng.ac.uk/ news-and-events/media-centre/press-releases/rcs-statement-onlatest-public-health-england-ppe-guidance/ [Accessed 21 April 2020].

10 Resuscitation Council UK. Statement on PHE PPE guidance. RCUK, 2020. Available from www.resus.org.uk/media/statements/ resuscitation-council-uk-statements-on-covid-19-coronaviruscpr-and-resuscitation/statement-on-phe-ppe-guidance/ [Accessed 21 April 2020].

11 Public Health England. COVID-19: infection prevention and control. PHE, 2020. Available from www.gov.uk/government/publications/ wuhan-novel-coronavirus-infection-prevention-and-control [Accessed 27 April 2020].

12 Ong SWX, Tan YK, Chia PY et al. Air, surface environmental, and personal protective equipment contamination by Severe Acute Respiratory Syndrome Coronavirus 2 (SARS-CoV-2) from a symptomatic patient. JAMA 2020, in press (DOI 10.1001/ jama.2020.3227).

13 World Health Organization. Modes of transmission of virus causing COVID-19: implications for IPC precaution recommendations. WHO, 2020. Available from www.who.int/news-room/commentaries/ detail/modes-of-transmission-of-virus-causing-covid-19-implicationsfor-ipc-precaution-recommendations [Accessed 29 March 2020].

14 Chan JF-W, Yuan S, Kok K-H et al. A familial cluster of pneumonia associated with the 2019 novel coronavirus indicating person-to-person transmission: a study of a family cluster. Lancet 2020 15;395:514-23.

15 Tellier R, Li Y, Cowling BJ, Tang JW. Recognition of aerosol transmission of infectious agents: a commentary. BMC Infect Dis 2019;19:101

16 Wang W, Xu Y, Gao R et al. Detection of SARS-CoV-2 in different types of clinical specimens. JAMA 2020, in press (DOI: 10.1001/ jama.2020.3786).

17 Yuen K-S, Ye Z-W, Fung S-Y, Chan C-P, Jin D-Y. SARS-CoV-2 and COVID-19: The most important research questions. Cell Biosci 2020;10:40.

18 Atkinson J, Chartier Y, Pessoa-Silva CL, Jensen P, Li Y, Seto W-H. Natural ventilation for infection control in health-care settings. World Health Organization, 2009.

19 Anfinrud P, Stadnytskyi V, Bax CE, Bax A. Visualizing speechgenerated oral fluid droplets with laser light scattering. N Engl ] Med 2020, in press (DOI: 10.1056/NEJMc2007800).

20 Nicas M, Nazaroff WW, Hubbard A. Toward understanding the risk of secondary airborne infection: emission of respirable pathogens. J Occup Environ Hyg 2005;2:143-54.

21 Gawn J, Clayton M, Makison C, Crook B. Evaluating the protection afforded by surgical masks [RR619]. Health and Safety Executive, 2008. Available from www.hse.gov.uk/research/rrhtm/rr619.htm [Accessed 30 March 2020].

22 Bourouiba L. Turbulent gas clouds and respiratory pathogen emissions: potential implications for reducing transmission of COVID19. JAMA 2020, in press (DOI: 10.1001/jama.2020.4756).
23 Tran K, Cimon K, Severn M, Pessoa-Silva C, Conly J. Aerosolgenerating procedures and risk of transmission of acute respiratory infections: a systematic review. CADTH Technol Overv 2013;3:e3101.

24 World Health Organization. Rational use of personal protective equipment (PPE) for coronavirus disease (COVID-19): interim guidance, 19 March 2020. WHO, 2020. Available from https://apps. who.int/iris/handle/10665/331498 [Accessed 30 March 2020].

25 Weber RT, Phan LT, Fritzen-Pedicini C, Jones RM. Environmental and personal protective equipment contamination during simulated healthcare activities. Ann Work Expo Health 2019;63:784-96.

26 Yan J, Grantham M, Pantelic J et al. Infectious virus in exhaled breath of symptomatic seasonal influenza cases from a college community. Proc Natl Acad Sci U S A 2018;115:1081-6.

27 Leung NHL, Chu DKW, Shiu EYC et al. Respiratory virus shedding in exhaled breath and efficacy of face masks. Nat Med 2020, in press (DOI: 10.1038/s41591-020-0843-2).

28 Bischoff WE, Swett K, Leng I, Peters TR. Exposure to influenza virus aerosols during routine patient care. J Infect Dis 2013;207:1037-46.

29 van Doremalen N, Bushmaker T, Morris DH et al. Aerosol and surface stability of SARS-CoV-2 as compared with SARS-CoV-1. N Engl J Med 2020;382:1564-7.

30 Cheng VCC, Wong S-C, Chen JHK et al. Escalating infection control response to the rapidly evolving epidemiology of the Coronavirus disease 2019 (COVID-19) due to SARS-CoV-2 in Hong Kong. Infect Control Hosp Epidemiol 2020, in press (DOI: 10.1017/ice.2020.58).

31 Santarpia JL, Rivera DN, Herrera V et al. Transmission potential of SARS-CoV-2 in viral shedding observed at the University of Nebraska Medical Center. medRxiv 2020;2020.03.23.20039446.

32 Lewis D. Is the coronavirus airborne? Experts can't agree. Nature 2020;580:175

$333 \mathrm{M}$. Respirators and surgical masks: a comparison. Available from: https://multimedia.3m.com/mws/media/9577300/respiratorsand-surgical-masks-contrast-technical-bulletin.pdf.

34 Lindsley WG, King WP, Thewlis RE et al. Dispersion and exposure to a cough-generated aerosol in a simulated medical examination room. J Occup Environ Hyg 2012;9:681-90.

35 Smith JD, MacDougall CC, Johnstone ] et al. Effectiveness of N95 respirators versus surgical masks in protecting health care workers from acute respiratory infection: a systematic review and meta-analysis. CMAJ Can Med Assoc J/J Assoc Medicale Can 2016;188:567-74.

36 Hui DS, Chow BK, Chu L et al. Exhaled air dispersion during coughing with and without wearing a surgical or N95 mask. PloS One 2012;7:e50845.

37 Long Y, Hu T, Liu L, Chen R, Guo Q, Yang L et al. Effectiveness of N95 respirators versus surgical masks against influenza: a systematic review and meta-analysis. J Evid-Based Med 2020, in press (DOI: 10.1111/jebm.12381).

38 Jefferson T, Del Mar CB, Dooley L et al. Physical interventions to interrupt or reduce the spread of respiratory viruses. Cochrane Database Syst Rev 2011;7:CD006207.

39 Bai Y, Yao L, Wei T et al. Presumed asymptomatic carrier transmission of COVID-19. JAMA 2020;323:1406-7.

40 Chang D, Xu H, Rebaza A, Sharma L, Cruz CSD. Protecting healthcare workers from subclinical coronavirus infection. Lancet Respir Med 2020;8:e13.

41 Verity R, Okell LC, Dorigatti I et al. Estimates of the severity of coronavirus disease 2019: a model-based analysis. Lancet Infect Dis 2020, in press (DOI: 10.1016/S1473-3099(20)30243-7).

42 World Health Organization. Infection prevention and control of epidemic-and pandemic-prone acute respiratory infections in health care. WHO, 2014. Available from www.who.int/csr/bioriskreduction/ infection_control/publication/en/.

43 Guo YP, Li Y, Wong PLH. Environment and body contamination: a comparison of two different removal methods in three types of personal protective clothing. Am J Infect Control 2014;42:e39-45. 
44 Verbeek JH, Rajamaki B, Ijaz S et al. Personal protective equipment for preventing highly infectious diseases due to exposure to contaminated body fluids in healthcare staff. Cochrane Database Syst Rev 2019;7:CD011621.

45 Tomas ME, Cadnum JL, Mana TSC, Jencson AL, Donskey C]. Seamless suits: reducing personnel contamination through improved personal protective equipment design. Infect Control Hosp Epidemiol 2016;37:742-4.

46 Chen L, Deng C, Chen X et al. Ocular manifestations and clinical characteristics of 534 cases of COVID-19 in China: A crosssectional study. medRxiv 2020;2020.03.12.20034678.

47 French CE, McKenzie BC, Coope C et al. Risk of nosocomial respiratory syncytial virus infection and effectiveness of control measures to prevent transmission events: a systematic review. Influenza Other Respir Viruses 2016;10:268-90.

48 Roberge RJ. Face shields for infection control: a review. J Occup Environ Hyg 2016;13:235-42.

49 Lindsley WG, Noti JD, Blachere FM, Szalajda JV, Beezhold DH. Efficacy of face shields against cough aerosol droplets from a cough simulator. J Occup Environ Hyg 2014;11:509-18.

50 Mukerji S, MacIntyre CR, Seale $\mathrm{H}$ et al. Cost-effectiveness analysis of N95 respirators and medical masks to protect healthcare workers in China from respiratory infections. BMC Infect Dis 2017;17:464.

51 Dan YY, Tambyah PA, Sim ] et al. Cost-effectiveness analysis of hospital infection control response to an epidemic respiratory virus threat. Emerg Infect Dis 2009;15:1909-16.

52 MacIntyre CR, Chughtai AA. Facemasks for the prevention of infection in healthcare and community settings. BMJ 2015;350:h694-h694.

53 Tzu S. The art of war. Available from http://ctext.org/art-of-war.

54 Vu YA, London WM, Vu YA, London WM. Precautionary principle. Oxford University Press; 2013.

55 Beauchamp T, Childress J. Principles of biomedical ethics: marking its fortieth anniversary. Am J Bioeth 2019;19:9-12.

56 Dyer C. NHS trusts must have legal duty to be open about harms to patients, Francis tells MPs. BMJ 2013;346:f988.

57 Oliver D. We need statutory duty of candour and transparency for NHS executives. BMJ 2017;359:j5111.

58 Artenstein AW. In pursuit of PPE. N Engl ] Med 2020, in press (DOI: 10.1056/NEJMc2010025).

59 Criddle C. Coronavirus: Dyson develops ventilators for NHS. BBC News, 24 March 2020. Available from www.bbc.com/news/ technology-52021757 [Accessed 24 March 2020].

60 Child D. Royal Mint to make 4,000 visors a day for NHS staff battling Covid-19 [Internet]. Evening Standard, 28 March 2020. Available from www.standard.co.uk/news/uk/royal-mint-tomanufacture-visors-for-nhs-staff-a4400556.html [Accessed 31 March 2020].

61 MacIntyre CR, Seale H, Dung TC et al. A cluster randomised trial of cloth masks compared with medical masks in healthcare workers. BMJ Open 2015;5:e006577.

62 British Thoracic Society. COVID-19: information for the respiratory community. BTS, 2020. Available from www.brit-thoracic.org.uk/ about-us/covid-19-information-for-the-respiratory-community/ [Accessed 31 March 2020].

63 Public Health England. Considerations for acute personal protective equipment (PPE) shortages. PHE, 2020. Available from www.gov. uk/government/publications/wuhan-novel-coronavirus-infectionprevention-and-control/managing-shortages-in-personal-protectiveequipment-ppe [Accessed 21 April 2020].

64 Fisher EM, Shaffer RE. Considerations for recommending extended use and limited reuse of filtering facepiece respirators in health care settings. J Occup Environ Hyg 2014;11:D115-28.

65 Wong J, Goh QY, Tan Z et al. Preparing for a COVID-19 pandemic: a review of operating room outbreak response measures in a large tertiary hospital in Singapore. Can ] Anaesth/] Can Anesth 2020, in press (DOI: 10.1007/s12630-020-01620-9).

66 National Institute for Occupational Safety and Health. Recommended guidance for extended use and limited reuse of $\mathrm{N} 95$ filtering facepiece respirators in healthcare settings. NIOSH, 2020. Available from: www.cdc.gov/niosh/topics/hcwcontrols/ recommendedguidanceextuse.html [Accessed 21 April 2020].

67 Roberge RJ, Coca A, Williams WJ, Powell JB, Palmiero AJ. Physiological impact of the $\mathrm{N} 95$ filtering facepiece respirator on healthcare workers. Respir Care 2010;55:569-77.

68 Radonovich LJ, Cheng J, Shenal BV, Hodgson M, Bender BS Respirator tolerance in health care workers. JAMA 2009;301:36-8.

69 Tingbo L, Yu L. Handbook of COVID-19 prevention and treatment. Zhejiang University School of Medicine; 2020.

70 European Centre for Disease Prevention and Control. Infection prevention and control for COVID-19 in healthcare settings. ECDP, 2020. Available from www.ecdc.europa.eu/en/publications-data/ infection-prevention-and-control-covid-19-healthcare-settings [Accessed 31 March 2020].

71 Centers for Disease Control and Prevention. Interim infection prevention and control recommendations for patients with suspected or confirmed coronavirus disease 2019 (COVID-19) in healthcare settings. CDC, 2020. Available from www.cdc.gov/coronavirus/2019-ncov/infection-control/control-recommendations.html [Accessed 31 March 2020].

72 Australian Government Department of Health. Interim recommendations for the use of personal protective equipment (PPE) during hospital care of people with Coronavirus Disease 2019 (COVID-19). Available from www.health.gov.au/resources/publications/interimrecommendations-for-the-use-of-personal-protective-equipmentppe-during-hospital-care-of-people-with-coronavirus-disease-2019covid-19 [Accessed 31 March 2020].

73 3M. Respirators for protection against PM2.5. 3M, 2016. Available from https://multimedia.3m.com/mws/media/13131430/respirators-for-protection-agains.pdf.

Address for correspondence: Dr John P Thomas, Department of Respiratory Medicine, Norfolk and Norwich University Hospital, Colney Lane, Norwich NR4 7UY, UK.

Email: drjohnpthomas@gmail.com 